УДК 342.24(470) (075.8)

\title{
В.Ю. Войтович
}

\section{О НЕКОТОРЫХ ТЕОРЕТИКО-ПРАВОВЫХ ОСНОВАХ ЗАДАЧ СОВРЕМЕННОЙ РОССИЙСКОЙ ГОСУДАРСТВЕННОСТИ}

В статье исследуются основные положения, связанные с реализацией целей российского государства, закрепленных в Конституции РФ. Они получили свое законодательное оформление в Политической программе государства, принципах, формах, целях, задачах и функциях ее реализации. Провозглашение в Конституции РФ построения демократического правового государства в качестве высшей цели имеет как теоретическое, методологическое, так и практическо-политическое и идеологическое значение. Отмечается, что демократизм общества отражается, прежде всего, в фактической реализации гражданами своих политических, социальноэкономических прав и свобод, в их активном участии в государственной и общественно-политической жизни, в управлении обществом не только через государственные органы, но и через систему местного самоуправления, общественных объединений. Сегодня можно с определенностью говорить о появлении такой функции, как социальная. Она выражена в основной программно-политической цели: повышение материального и культурного уровня жизни трудящихся России.

Ключевые слова: Конституция РФ, теоретико-правовые основы, демократическое, правовое государство, российская государственность.

DOI: $10.35634 / 2412-9593-2020-30-5-714-719$

Конституция РФ является Законом России, обладающим высшей юридической силой. Таково ее официальное наименование, хотя во многих источниках ее определяют Основным законом. Да, это Основной закон, но не официальное наименование, зафиксированное ст. 15 Конституции Российской Федерации. При этом природа Конституции не сводится только к указанному качеству. Она является не только юридическим актом, но и важнейшим политическим документом, определяющим дальнейшее развития общества и государства, провозглашает основные задачи и цели формирования демократического правового государства ${ }^{1}$.

Неоднозначность природы закона, обладающего высшей юридической силой, сочетание в нем юридического и политического начал являются главными особенностями, отличающими новую Конституцию РФ от всех советских конституций социалистического типа.

Конституция РФ как политический документ содержит, с учетом внесенных поправок, прежде всего программные цели. Особенно важное значение имеет провозглашение демократического правового государства, в котором полноценно развивается гражданское общество, правосознание граждан.

Программные положения, зафиксированные гл. 1 Конституции РФ и те ее положения, в которых закреплены достигнутые результаты общественного развития, естественно, неоднозначны. Однако они ни в коей мере не противостоят друг другу. В связи с этим включение в Конституцию программных положений, подчеркивает ее творческую роль, не отождествляя ее с программой. Также закрепление в Законе, обладающем высшей юридической силой, достижений в области совершенствования элементов общественного устройства, не превращает Конституцию в просто фиксацию итогов проделанной работы и пройденного пути. Конституция РФ сочетает закрепление исторических завоеваний, достигнутых народом России, с программными положениями, с новыми задачами, которые еще предстоит решать.

Большое внимание программным установкам уделяется в Преамбуле Конституции. В ней раскрывается прочная диалектическая взаимосвязь прошлого, настоящего и будущего. Эта «связь времен» выражена в Преамбуле Конституции РФ в следующих данных:

- в сохранении памяти предков, передавших нам любовь и уважение к Отечеству, веру в добро и справедливость;

- в закреплении факта возрождения исторической государственности России и утверждения незыблемости ее демократической основы;

\footnotetext{
${ }^{1}$ Войтович В.Ю. Теоретико-правовые основы роли Конституции РФ в реализации политических задач государства // Вестн. Удм. ун-та. Сер.: Экономика и право. 2019. Т. 29, вып. 1. С. 70-76.
} 
- в четкой фиксации высшей цели российского государства и его главных задач, то есть конституционно закрепляются программные установки.

Провозглашение в Конституции РФ построения демократического правового государства в качестве высшей цели имеет как теоретическое, методологическое, так и практическо-политическое и идеологическое значение. Прежде всего, это показатель того, что в России создано развитое общество, что наше государство является общенародным.

Конституции РФ присущ научный диалектический подход к раскрытию понятия всенародного государства, в котором единственным источником власти является многонациональный народ, а права и свободы человека - высшей ценностью. В ней, прежде всего, определены природа и цели российского государства как государства нового типа. Это общие наиболее существенные черты нашего государства как общенародного многонационального государства. Наряду с определением демократического правового государства, Конституция РФ всесторонне раскрывает особенности общенародного государства. Это государство определенного исторического этапа, государство нового типа, соответствующее развитому обществу.

Как определено в ст. 1, 7, 14 Конституции РФ Российская Федерация - демократическое федеративное правовое, социальное и светское государство, выражающие волю и интересы граждан, всех наций и народностей страны. В этом состоит общенародная сущность государства, России на новом этапе ее развития. В Конституции РФ сущность государства выражена в ряде принципиальных положений, и одно из них (главное) - конституционное закрепление его программно-политической цели. Так, с политической точки зрения для того, чтобы установить, какова сущность данного исторически конкретного государства, необходимо ответить на следующие вопросы: кто формирует органы государственной власти; в чьих руках находится государственная власть; каким путем и в каких целях она осуществляется. Как видим, в Конституции РФ содержатся исчерпывающие ответы на все поставленные вопросы. Относительно принадлежности государственной власти четко определено пп. 1,2,3 ст. 3 Конституции РФ, что высшая цель государства - обеспечить высокий социальный уровень своего народа.

Таким образом, признак «цели» является одним из существенных политических признаков, характеризующих природу (сущность) российского государства. Методологическое значение данного признака состоит еще и в том, что с его учетом полнее и отчетливее прослеживаются этапы развития нашего государства, в исторических рамках которых происходило перерастание государства диктатуры пролетариата в демократическое правовое государство - гражданское общество. Если историческая миссия государства диктатуры пролетариата состояло в том, что оно главное орудие строительства социализма - развитого, зрелого, то российское государство выступает основным орудием строительства конституционного государства, в котором человек, его права и свободы являются высшей ценностью 2 .

Закрепление в Конституции РФ в качестве высших целей государства торжества демократизма, выражающегося в народном суверенитете; разделении властей; идеологическом и политическом многообразии; в признании и гарантировании местного самоуправления, а также в утверждении демократического федеративного правового, социального, светского государства имеет также большое политическое и идеологическое значение. В этой связи необходимо привести слова основателя социалистического государства В.И. Ленина, который неоднократно характеризовал проблемы государства как фокус «всех политических вопросов и всех политических споров современности» ${ }^{3}$. К сожалению, и поныне вопросы государства, демократии, политической системы общества находятся в центре идеологической и политической борьбы между Россией и западными странами. По-прежнему одним из острейших вопросов в этой непримиримой борьбе остается вопрос о соотношении российской государственности и демократии - народного самоуправления. Некоторые лица не хотят видеть главного - диалектики нашего государственного и общественного развития, которая состоит в том, что с ростом правосознания граждан России, упрочения и развития местного самоуправления, неуклонно развивается гражданское общество.

Вопрос о диалектике нашего государственного и общественного развития характеризуется рядом аспектов, каждый из которых играет существенную методологическую роль. Так, вне диалектики развития государственного и общественного нельзя в полной мере уяснить и раскрыть само понятие самоуправления, тем более что в литературе термин «самоуправление» применяется в разных значениях.

\footnotetext{
${ }^{2}$ Войтович В.Ю. Проблемы и практическая реализация законмоерностей функционирования и развития системы государтсвенно-административного управления // Наука Удмуртии. 2018. № 3 (85). С. 18-22.

3 Ленин В.И. Полн. собр. соч. Т. 39. С. 80.
} 
Что касается Конституции РФ, то в ней термин «самоуправление» применяется в строго определенном смысле - это способ организации и осуществления власти на местах, который обеспечивает самостоятельное решение гражданами вопросов местного значения, через представительные (выборные) органы власти, местную администрацию, местные референдумы, собрания граждан (сходы), иные территориальные формы непосредственной демократии, а также органы территориального общественного самоуправления. Не являясь частью системы государственных органов, органы местного самоуправления, как и все местное самоуправление в целом, - это не только форма самоорганизации населения для решения своих задач, но также форма осуществления публичной власти, власти народа. Поэтому деятельность органов местного самоуправления характеризуется такими свойственными органам государственной власти чертами, как наличие властных полномочий, обязательность принимаемых решений для всех физических лиц, а также юридических лиц и организаций, находящихся на территории, в рамках которой действуют соответствующие органы местного самоуправления.

Конституция РФ исходит из того, что к общественному самоуправлению ведет путь всестороннего развертывания демократических основ, путь сотрудничества и совместной деятельности государственных органов и органов местного самоуправления, общественных организаций в рамках развития единой системы демократии. В связи с этим комплексный подход к решению задач развития демократических основ является характерной чертой политики органов государственной власти Российской Федерации. Вместе с тем в развертывании демократических основ выделяется «стержневой вопрос», выражающий смысл и главное содержание демократии и являющийся критерием ее развития - это участие граждан в решении государственных и общественных дел.

Из изложенного необходимо сделать вывод о том, что демократия и самоуправление объединяются друг с другом, выступают как явление единства. Это положение представляется существенным для раскрытия демократической природы нашего государства как организации, выражающей волю и интересы многонационального народа и обеспечивающей его участие в реализации государственной программы. Необходимо отметить, что в отечественной специальной литературе и прежде «общественное самоуправление» не противопоставлялось «народной государственности». Однако их сочетание и переплетение - объективное свойство демократических основ. Отнюдь не ставя под сомнение правильность приведенного положения, мы тем не менее ведем речь не о «сочетании и переплетении» указанных социальный явлений (и понятий), из коих одно - самоуправление (общественное), а другое - не самоуправление (народное государство). Более того, российское общенародное государство по своей демократической природе выступает как «народное самоуправление» ничуть не в меньшей степени, чем «общественное самоуправление».

В свое время М.И. Калинин отмечал, что ни одна другая организация трудящихся, какой бы массовой она не была, не может конкурировать с Советами по охвату масс ${ }^{4}$. Эти слова в еще большей степени справедливы сегодня. Конституция РФ впервые наравне с законодательной, исполнительной, судебной властью утвердила власть муниципальную. Таким образом, появился пятый основной элемент - местное самоуправление. Это подтверждение того, что не только расширяются, но и углубляются демократические основы, и прежде всего это выражается в развитии демократических принципов, их гарантий, в формировании и деятельности местного самоуправления.

На этапе демократического правового государства развитие и совершенствование местного самоуправления (что мы наблюдаем в его системном реформировании) характеризуются многими показателями. Прежде всего, получили дальнейшее развитие демократические основы избирательной системы, а сами выборы в местное самоуправление прочно стали формой все более широкого участия многонационального народа России в управлении делами на местах. На всех этапах проведения избирательных кампаний в Российской Федерации голос многонационального народа, коллективов трудящихся имеет решающий и неоспоримый вес.

Местное самоуправление обеспечивает не только самостоятельность решений населением всех вопросов местного значения, но и организационное обособленное управление местными делами в системе управления обществом и государством. Согласно Конституции РФ, органы местного самоуправления не входят в систему органов государственной власти. В этом смысле также можно отметить самостоятельность местного самоуправления в рамках его полномочий. Осуществление местного самоуправления в Российской Федерации обеспечивается рядом конституционных гарантий, пред-

\footnotetext{
${ }^{4}$ См.: Калинин М.И. Вопросы советского строительства. Статьи и речи (1919-1946). М., 1958. С. 201.
} 
ставляющих собой правовые средства обеспечения его деятельности. Они являются важнейшим условием полного и эффективного осуществления местным самоуправлением своих задач и функций.

В соответствии с высшей целью российского государства - обеспечение достойного в материальном отношении существования человека и его свободного развития, преодоление неоправданных социальных различий Конституция РФ определяет его главные задачи - обеспечить каждому гражданину достойный человека прожиточный минимум, социальное равенство; создать условия, обеспечивающие достойную жизнь и свободное развитие человека; обеспечить охрану труда и здоровья; обеспечить государственную поддержку семьи, инвалидов и пожилых граждан; установить государственные пенсии, пособия и иные гарантии социальной защиты; обеспечить безопасность страны, содействовать укреплению мира и развитию международного сотрудничества. Как видим, в Конституции, ее поправках дается развернутый перечень главных задач государства во всех основных сферах общественной жизни, включая сферу внешней политики.

Необходимо отметить, что в Конституции РФ содержится развернутая предметная характеристика всех важнейших функций государства в лице его органов, основных направлений и сторон его деятельности по решению поставленных задач. В этой связи вопрос об основных функциях государства на современном этапе потребовал дальнейшей научной разработки, что мы видим в соответствующих поправках к Конституции РФ. Поставленные задачи обусловливают осуществление российским государством соответствующих функций, определяются их содержание, формы и методы осуществления. Эти задачи придают функциям государства целенаправленный, целеустремленный характер. Как уже отмечалось, закрепленные в Конституции РФ главные задачи демократического правового государства направляют его деятельность на создание условий, обеспечивающих достойную жизнь и свободное развитие человека. При этом функции государства служат решению стоящих перед ним задач. Вне функции государства его задачи останутся нерешенными. Таким образом, взаимосвязь задач и функций государства ведет к эффективной реализации политической программы. В развитии этого направления деятельности в ст. 7 Конституции, соответствующих поправках закреплен широкий комплекс сторон и видов государственной деятельности, необходимый для решения задач.

Однако «повышение уровня жизни народа» и «удовлетворение его потребностей» - это понятия, которые по своей природе и содержанию относятся не только к функциональной характеристике российского государства. Повышение народного благосостояния - это прежде всего высшая цель политики органов государственной власти России. Из вышеизложенного следует, что наше государство решает не одну, а широкий комплекс задач, органически связанных между собой. Вместе с тем на современном этапе каждая из главных задач демократического правового государства носит комплексный характер. Это требует всестороннего решения государством задач общественного развития, то есть совокупности мероприятий для их решения во всех сферах общественной жизни.

Обычно соотношение между главными задачами и функциями рассматривают в двух аспектах. Условно их называют «конкретными» и «общими». Первые из них выражают преимущественную связь каждой функции государства с определенной главной задачей. Иначе говоря, каждая основная функция имеет «свою» подфункцию (задачу), равно как и наоборот. Например, задаче улучшения благосостояния человека и общества в наибольшей мере соответствует хозяйственно-организаторская функция. $\mathrm{C}$ другой стороны, решение этой главной задачи социального государства не может быть обеспечено осуществлением только хозяйственно-организаторской функции. Поэтому необходимо рассмотреть второй аспект взаимосвязи главных задач и функций государства, который выражает уже всеобщую связь всей совокупности его задач и функций. Сущность ее состоит в том, что в решении каждой из перечисленных в Конституции РФ политических задач государства участвуют все до одной его основные функции, как внутренние, так и внешние.

На основании изложенного можно сделать вывод, что в общенародном государстве в соотношении между главными задачами и функциями должна проявлять себя следующая тенденция: все большее развитие должна получать взаимосвязь основных функций государства с его главными задачами. В основе указанной тенденции должен лежать комплексный подход к решению главных задач российского государства.

Задачи, стоящие перед государством, на разных этапах его развития, не произвольны. Они обусловлены определенными достижениями в области политической системы, уровнем развития производительных сил, зрелостью социально-культурных общественных отношений, а также особенностями международной обстановки. Естественно, что эти объективные конкретно-исторические условия 
изменения основных элементов общественного устройства государства предопределяли и относительно узкие границы развития основных функций Советского государства. И напротив, множественность и масштабность задач, стоящих перед нашим государством на современном этапе, повлекли за собой всестороннее развитие системы его основных функций.

Выделить развитие функций современного демократического правового государства как системы, - значит отметить его существенную особенность в условиях многонационального государства. В исторической действительности, на начальных этапах строительства социализма Советское государство решало задачи, поставленные перед ним ходом революционных событий, поочередно, одну за другой. Соответственно, акцент делался в большей мере на отдельных функциях государства, нежели на развитии их системы. Теперь же, в новейшее время, опираясь на высокоразвитые производительные силы, передовую индустрию, на высокомеханизированное сельское хозяйство, учитывая серьезные изменения, происходящие в социальной структуре нашего общества, общенародное государство успешно решает задачи одновременно по всем направлениям эффективной реализации политической программы. В результате изменился и сам характер развития основных функций современного государства: получило дальнейшее совершенствование вся система функций государства, их взаимодействие и особенно взаимозависимость.

Развитие функций российского государства в условиях совершенствования демократических основ происходит различными путями. Множественность путей и направлений - также одна из особенностей развития основных функций государства на современном этапе. При этом наиболее примечательно то, что системно появляются новые основные функции государства, они пополняют и развивают системы функций качественно новыми направлениями. Сегодня можно с уверенностью говорить о появлении такой функции, как социальная. Об этой функции сейчас много говорится во всех средствах массовой информации, как в нашей стране, так и за рубежом. В то же время нельзя не признать, что научная разработка социальной функции делает лишь первые шаги. К сожалению, в среде ученых нет единодушия в решении вопросов о содержании и внутренней структуре социальной функции, о ее точном наименовании, границах и особом месте в системе основных функций демократического правового государства. Однако имеющиеся разногласия в решении указанных вопросов не опровергают, а напротив, подкрепляют общий принципиальный вывод о системном развитии данной основной функции, нацеленной преимущественно на решение задач социального преумножения и развития.

Сегодня, как никогда, начинает реализовываться функция, зафиксированная ст. 7 Конституции РФ, она по праву заняла основополагающее место в системе функций нашего многонационального государства. Это подтверждается масштабами реализации социальной политики органами государственной власти России.

Войтович Валерий Юрьевич, доктор юридических наук, профессор, профессор кафедры «Государственное и муниципальное управление» ФГБОУ ВО «Удмуртский государственный университет» 426034, Россия, г. Ижевск, ул. Университетская, 1 (корп. 4) E-mail: gimu4282@inem.uni.udm.ru

\section{V.Yu. Voitovich ON SOME THEORETICAL AND LEGAL FOUNDATIONS OF THE PROBLEMS OF MODERN RUSSIAN STATEHOOD}

DOI: $10.35634 / 2412-9593-2020-30-5-714-719$

The article examines the main provisions related to the implementation of the goals of the Russian state, enshrined in the Constitution of the Russian Federation. They received their legislative form in the Political program of the state, principles, forms, goals, tasks and functions of its implementation. The proclamation in the Constitution of the Russian Federation of building a democratic legal state as the highest goal has theoretical, methodological, practical-political and ideological significance. It is noted that democracy is reflected, above all, in the actual implementation of citizens' political, social and economic rights and freedoms, their active participation in public and political life, in the manage- 
ment of the society not only through state agencies but through a system of local government, public associations. Today we can speak with certainty about the emergence of such a function as social. It is expressed in the main program and political goal: to increase the material and cultural standard of living of Russian workers.

Keyword: Constitution of the Russian Federation, theoretical and legal foundations, democratic, legal state, Russian statehood.

Vojtovich V.Yu., Doctor of Law, Professor at Department "State and municipal management" Udmurt State University

Universitetskaya st., 1/4, Izhevsk, Russia, 426034

E-mail: gimu4282@inem.uni.udm.ru 